\title{
Increasing the Process Cycle Efficiency of Men's Trousers Assembly Line
}

\author{
Duygu Selen Kansul, Gülseren Karabay \\ Dokuz Eylul University, Textile Engineering Department, İzmir, Turkey
}

\begin{abstract}
Value is known as the price, which the customer is ready to pay for and the ultimate customer defines the value. Eliminating the waste is important for reduction of costs and meeting the demands of customers in short delivery times. Process Cycle Efficiency (PCE) is defined as the measurement of the amount of value-added time in a process. In this study, the PCE of men's trousers assembly line was tried to be increased. To achieve this aim, the value stream map of the line was examined. Overall equipment efficiency (OEE) values of the operations were calculated, the operations with OEE values under $85 \%$ were selected, and improvement activities were defined. At the end of these activities, total process lead time and work in process (WIP) stocks decreased and PCE increased from $0.9 \%$ to $1.5 \%$.
\end{abstract}

\author{
ARTICLE HISTORY \\ Received: 18.12 .2018 \\ Accepted: 28.08.2019

\section{KEYWORDS} \\ Value stream mapping, lean, \\ process cycle efficiency, \\ overall equipment efficiency, \\ process lead time, work in \\ process, assembly line
}

\section{INTRODUCTION}

The apparel industry has a volatile structure with a high variation in product mix, small order quantities and short delivery times. In order to be competitive and to fulfil the orders on time, the companies have to be flexible to produce a high variety of models [1]. To be competitive, many apparel companies have to improve their manufacturing processes, constantly revise themselves according to the needs and expectations of their customers. Manufacturing processes have to be analyzed accurately to minimize the costs. Waste consumes resources but does not add any value to the product [2]. Toyota production system accepted the waste types as overproduction, waiting, transport, inappropriate processing, unnecessary inventory, unnecessary motion, defects [3].

Lean thinking is doing more with less and it starts with value [4]. Value is known as the price which is the customer is ready to pay for and the ultimate customer defines the value. A value stream can be described as any value-adding and non-value-adding activities, which are done to make a product. Value stream mapping (VSM) is one of the most important tools for lean strategy with its visualization the non-value adding activities in the material and information flow of product. Wastes should be visualized and VSM is a very useful tool as it underlines kaizen activities for waste reduction. The first step in VSM is to choose a product family as the target for improvement [5]. The second step is to identify the wastes by drawing current value stream map. Unlike most process mapping techniques that often only document the basic product flow, VSM also documents the flow of information within the system. Where the materials are stored (raw materials and WIP) and what triggers the movement of material from one process to the next are key pieces of information [1]. The final stage in VSM is to create the future state map. The future state map highlights the lean

To cite this article: Kansul DS, Karabay G. 2019. Increasing the process cycle efficiency of men's trousers assembly line. Tekstil ve Konfeksiyon 29(3), 253-262. 
tools, which are needed to eliminate the waste in the product value stream [6].

OEE is one of basic tools in lean manufacturing and it is an indicator, which defines the waste points in VSM. OEE is the measure of efficient usage of time for producing quality product. While the OEE is calculated, the time, which the machine is producing, is taking into account, not the amount of the output [7]. The waste hinders the capacity and performance. Machine breakdowns, setup and adjustments, reduced speed, minor stoppages, quality losses are the causes of low OEE. By removing waste in the manufacturing processes, the companies can manage to meet the demands with shorter lead time, high quality and they can get a competitive advantage over the other companies in recent volatile conditions by having flexibility to change schedules and giving priorities more quickly [8]. The studies in the literature, some of which are given below, show that lean principles can be applied to apparel companies.

Kumar and Thavaraj identified the target areas of improvement to eliminate the process wastages in current state. They fixed the problem of low flexibility by cellular layout, kaizen and 5s tools [6].

Kumari et al. applied lean tools in an apparel company in order to reduce the WIP and the number of workers by removing checking operations [9].

Akcagun et al. outlined a case study in an outerwear company. They decreased the total process of outwear from 27-33 weeks to 9-14 weeks by using value stream mapping [10].

Y1ldiz and Guner analyzed the manufacturing processes from incoming quality control to shipping to eliminate the wastes in a jean producing company [11].

Silva revealed that VSM can be applied to mass production in apparel industries in order to derive positive results such as reducing wastes in inventory and defects. Current and future state VSM was drawn for analyzing the raw material, cutting, sewing and finish goods departments' processes [12].

Kumar used VSM as a key lean tool to analyze machine cycle time, inventory, setup time and information flow on men's trouser production layout. Sewing room was revised by VSM analysis. [13].

Most of these studies try to decrease the total process lead time of a product from supplying process to shipment by using lean production principles and methods. In these studies, value stream mapping, kaizen, 5S and SMED applications were explained in detail with case studies. However, OEE and PCE were not the main topic of these studies. In this research, it was tried to determine and decrease the non-value-added time and eventually, to improve the rate of process cycle efficiency in the men's trousers production line by the help of lean principles. As defined before, OEE is an indicator, which defines the waste points in VSM. This research was conducted with the aim of emphasizing the importance of OEE and showing its application in an apparel company in detail as an example for other apparel companies.

\section{Value Stream Mapping, Process Cycle Efficiency and Overall Equipment Efficiency}

When creating a flowchart of a garment, the cycle times of all the operations in a line are summed and the line with the longest duration is determined as the mainline. Lines which have shorter durations are segment lines and they are located outside of the mainline and they join the mainline at the related matching points. The difference between the duration of the segment and mainline is also important in the management of work in processes (WIP). The sewing process starts in the segments and the mainline at the same time and the segments create overstock at the points where they join the mainline. In order to determine the optimum WIP in a segment, the duration of the segment and the duration in the mainline from the first operation to the last operation, where the segment joined the mainline, should be compared. The difference between these two durations causes WIP inventory. WIP stock is very important for making improvements and reducing waste time.

Cycle time (CT) is the time, which takes to complete the production of one unit from start to finish. Cycle time is consisting of value-added and non-value-added times. Value-added time is the process time part of cycle time, which elapses during making the activities, which are defined as value by the customer. Cycle time equals the process time of the task in the garment assembly line. The cycle time of the operation is the ideal time for finishing that operation, however, in real life, the production conditions, which are measured by OEE, can deviate this balance.

Overall Equipment Effectiveness (OEE) is a simple metric, which shows how much right-first-time product is produced at a single equipment in the given time. In other words, it measures how effectively the time is used to produce a quality product at that equipment. OEE can be calculated with equation (1) and the following sub-equations (2), (3), (4).

OEE $=$ PerformanceXAvailabilityXQuality
Performance $=\frac{\text { Actual outputXCycle time }}{\text { Daily working time } X \text { Workload }} X 100$
Availibility $=\frac{\text { (Daily working hours-Breakdown and adjustment times) }}{\text { Daily working time } X \text { Workload }}$ X100
Quality $=\left(1-\frac{\text { Daily repairing time }}{\text { Daily working time } X \text { Workload }}\right) * 100$

OEE value of $100 \%$ is the sign of perfect production, which means manufacturing right-first-quality product without time loss. Adversely, OEE value of under $100 \%$ is accepted 
as loss factor and OEE percentages should be used to define the actual cycle time(ACT) as in equation (5).

$\mathrm{ACT}=\frac{\mathrm{CT}}{\mathrm{OEE}}$

The actual cycle time will cause longer process lead time (PLT). Process lead time is the total time for a unit product to go its way through the operation from starting with the raw material's arrival to receiving money and can be calculated with equation (6). Process lead time is consisting of waiting time before the process, setup time, process time, waiting time after the process and transfer time between processes. The lead time of an operation should not be much higher than the cycle time of that operation, otherwise, there will be an overstock of WIP and this will decrease the process cycle efficiency of the line. Total process lead time is the sum of process lead times of all operations in the line.

PLT $=$ ACT $X$ WIP

Process cycle efficiency (PCE) means that the duration of one job from the beginning of production to the arrival of the warehouse is completed in the shortest time.

PCE is improved by reducing non-value adding activities, and minimizing the necessary but non-value adding activities. In reality, the PCE is typically in the 5\% to $10 \%$ range. While the PCE is the efficiency of the whole assembly line, OEE is valid only for one operation. PCE can be calculated with equation (7).
PCE $=\frac{\text { Total cycle time }(\text { total value }- \text { added time })}{\text { Total Process lead time }}$

VSM shows the current situation in the line and it is easy to detect OEE values less than $85 \%$ and high WIP inventories. These are the key places, which have to be improved.

\section{MATERIAL AND METHOD}

In this study, the OEE values of the operations were used in order to make improvements and increase the process cycle efficiency in the apparel company. Daily work time is 540 minutes and daily customer demand is 450 pieces. Men's trousers line was chosen as the product family. Men's trousers are made of belt and pocket preparation, front and back pants mounting sections. The cycle time of each operation is measured with the help of a stopwatch. WIP stock of each operation was counted three times a day for both current and future states. The average value of these three WIP stocks were used as WIP quantities in each operation. OEE values of each operation were calculated by using collected performance, machine availability and quality data. After WIP stock and cycle time of each operation are determined, actual cycle times of operations were calculated by using OEE values. Process lead times of operations were found by using the actual cycle times and WIP levels of operations. VSM of the men's trousers assembly line was generated, by sequencing the unit cell of each operation. Figure 1 shows a unit cell of this VSM. After defining the current cycle time (process time), WIP, OEE, process lead time data, current process cycle efficiency of men's trousers production line was calculated.

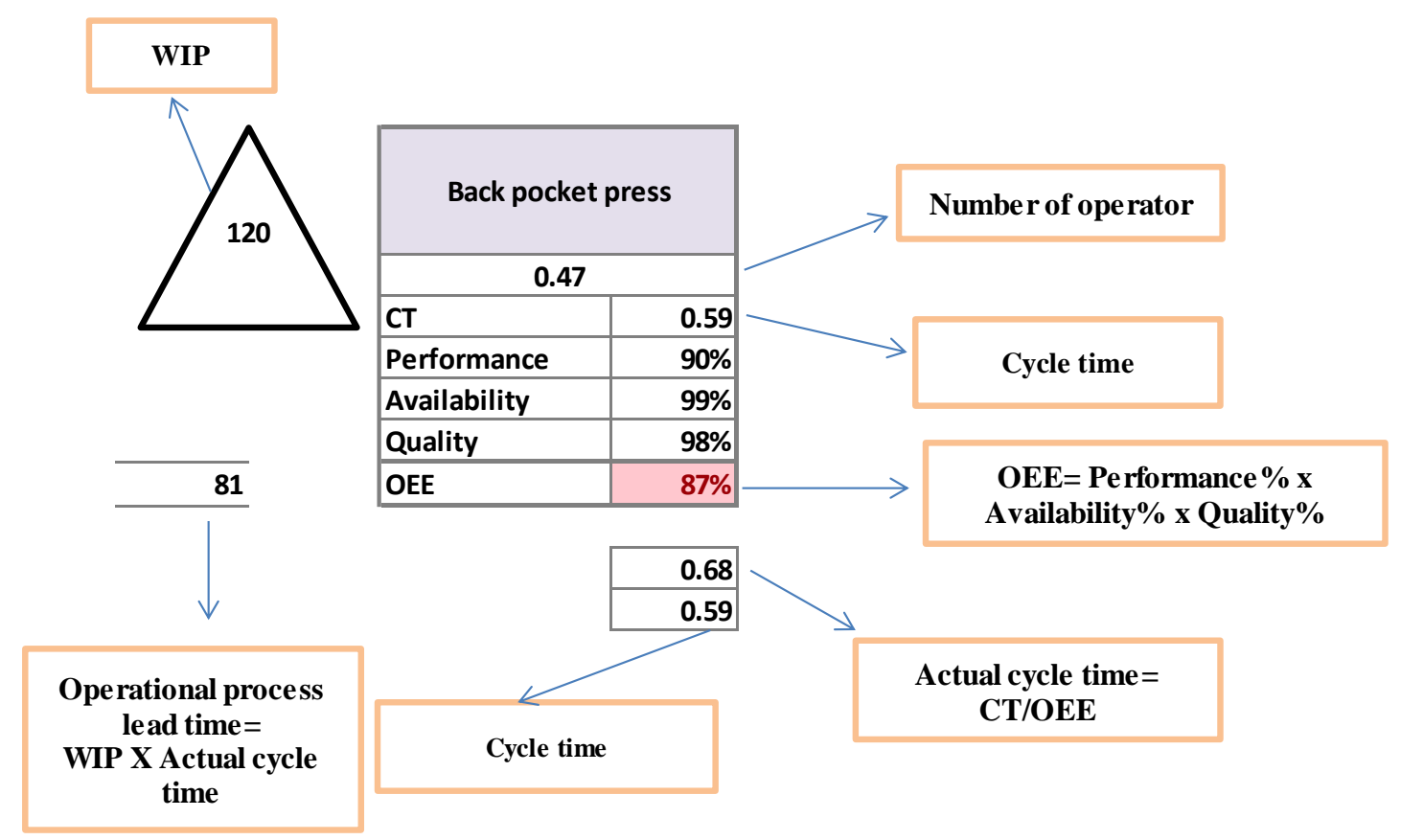

Figure 1. A unit cell of a value stream 
Calculations of above operation were given in the following lines as an example. The daily target was 450 pieces and the daily working time is 540 minutes. Cycle time (CT) is 0,59 minutes. The operator produced 404 piece/day. The counted average WIP stock for this operation is 120 pieces. Machine breakdown is 278 minutes and repairing time is 5 minutes.

The related calculations were made for all operations in the line. All of these values were written on the VSM in Figure 2 .

Workload $=\left(\frac{\text { Daily target XCycle time }}{\text { Daily working time }}\right)=\frac{450 \text { X0,59 }}{540}=0,49$

Performance $=\frac{\text { Actual outputXCycle time }}{\text { Daily working time X Workload }} \times 100=\frac{404 X 0,59}{540 X 0,49} \times 100=90 \%$

Availibility $=\frac{\text { (Daily working hours-Breakdown and adjustment times) }}{\text { Daily working time X Workload }} X 100=\frac{540-278}{540 \times 0,49} X 100=99 \%$

Quality $=\left(1-\frac{\text { Daily repairing time }}{\text { Daily working time X Workload }}\right) * 100=\left(1-\frac{5}{540 \times 0,49}\right) X 100=98 \%$

OEE $=$ PerformanceXAvailabilityXQuality $=90 \% X 99 \% X 98 \%=87 \%$

\section{Segment 1(Belt preparation line)}

\begin{tabular}{|c|c|c|c|c|c|c|c|c|c|c|c|}
\hline \multirow{6}{*}{467} & \multicolumn{2}{|c|}{ Belt fusing } & \multirow{6}{*}{250} & \multirow{2}{*}{\multicolumn{2}{|c|}{$\begin{array}{c}\text { Belt lining } \\
0,45\end{array}$}} & \multirow{6}{*}{100} & Loop attac & ing & \multirow{6}{*}{160} & \multirow{2}{*}{\multicolumn{2}{|c|}{$\begin{array}{c}\text { Waistband press } \\
0,96\end{array}$}} \\
\hline & \multicolumn{2}{|r|}{0,32} & & & & & \multicolumn{2}{|l|}{0,3} & & & \\
\hline & СТ & 0,26 & & CT & 0,47 & & CT & 0,35 & & CT & 0,9 \\
\hline & Performance & $100 \%$ & & Performance & $99 \%$ & & Performance & $102 \%$ & & Performance & $100 \%$ \\
\hline & Availability & $100 \%$ & & Availability & $98 \%$ & & Availability & $95 \%$ & & Availability & $99 \%$ \\
\hline & Quality & $99 \%$ & & Quality & $100 \%$ & & Quality & $89 \%$ & & Quality & $95 \%$ \\
\hline 123 & OEE & $99 \%$ & 121 & OEE & $97 \%$ & 41 & OEE & $86 \%$ & 153 & OEE & $94 \%$ \\
\hline & & 0,26 & & & 0,48 & & & 0,41 & & & 0,96 \\
\hline & & 0,26 & & & 0,47 & & & 0,35 & & & 0,9 \\
\hline
\end{tabular}

\section{Segment 2 (Pocket preparation line)}

\begin{tabular}{|c|c|c|c|c|c|}
\hline \multirow{6}{*}{660} & Pocket facin & seam & \multirow{6}{*}{436} & \multirow{2}{*}{\multicolumn{2}{|c|}{$\begin{array}{c}\text { Fusing fly } \\
0,16\end{array}$}} \\
\hline & \multicolumn{2}{|r|}{1,04} & & & \\
\hline & CT & 0,98 & & CT & 0,17 \\
\hline & Performance & $98 \%$ & & Performance & $99 \%$ \\
\hline & Availability & $80 \%$ & & Availability & $100 \%$ \\
\hline & Quality & $91 \%$ & & Quality & $100 \%$ \\
\hline 907 & OEE & $71 \%$ & 75 & OEE & $99 \%$ \\
\hline & & 1,37 & & & 0,17 \\
\hline & & 0,98 & & & 0,17 \\
\hline
\end{tabular}

\begin{tabular}{|c|c|}
\hline \multicolumn{2}{|c|}{ Pressing fly lining } \\
\hline \multicolumn{2}{|l|}{0,21} \\
\hline CT & 0,15 \\
\hline Performance & $77 \%$ \\
\hline Availability & $100 \%$ \\
\hline Quality & $100 \%$ \\
\hline OEE & $77 \%$ \\
\hline
\end{tabular}

OEE values were examined in VSM and the operations, which have OEE values under $85 \%$ were determined for improvement. After doing the planned activities, before and after values of PCE were compared.

\section{RESULTS AND DISCUSSION}

The value stream of material and information flow of the current situation in the men's trousers line is as in Figure 2. 
Mainline (Front piece)

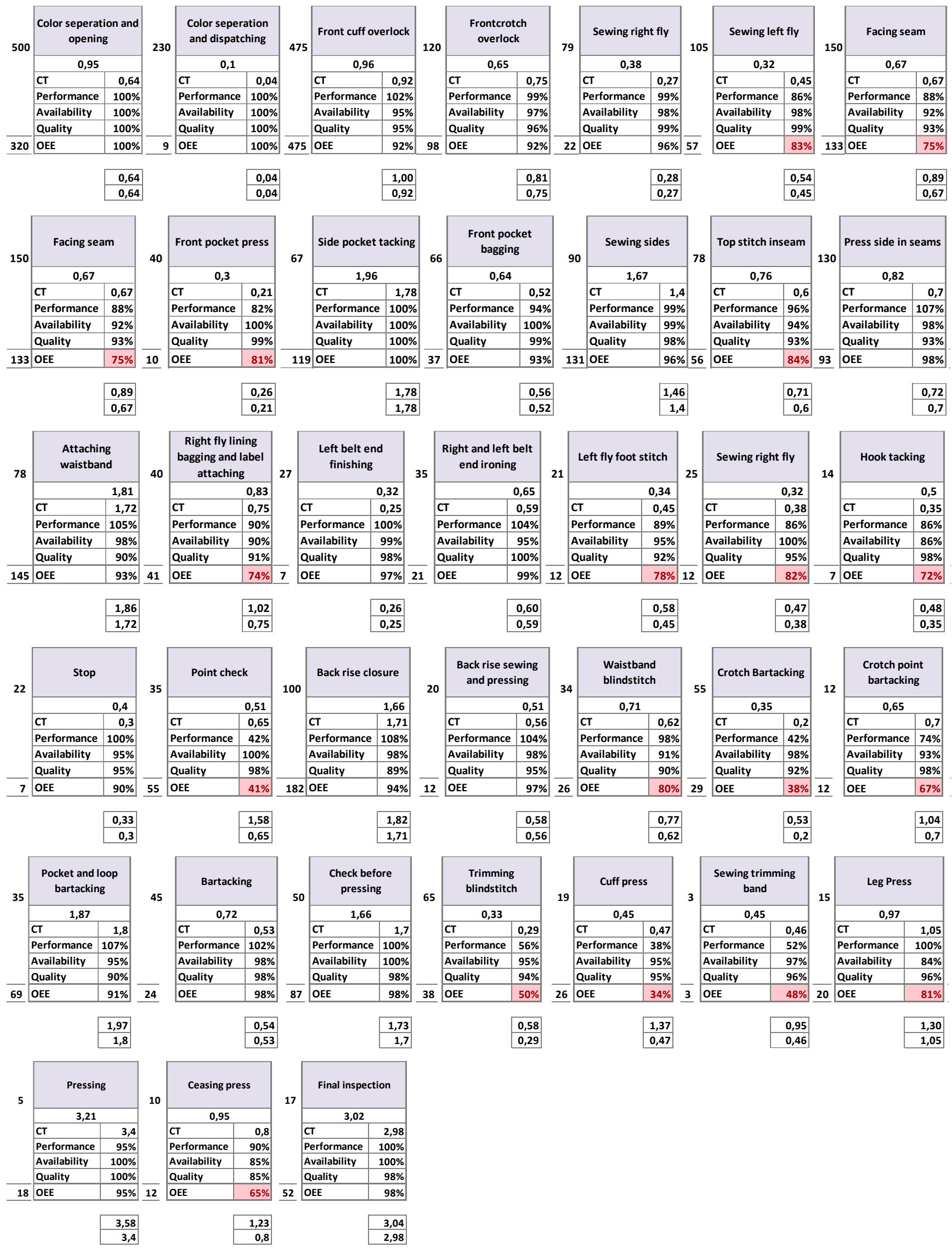


Segment 3 (Back Piece)

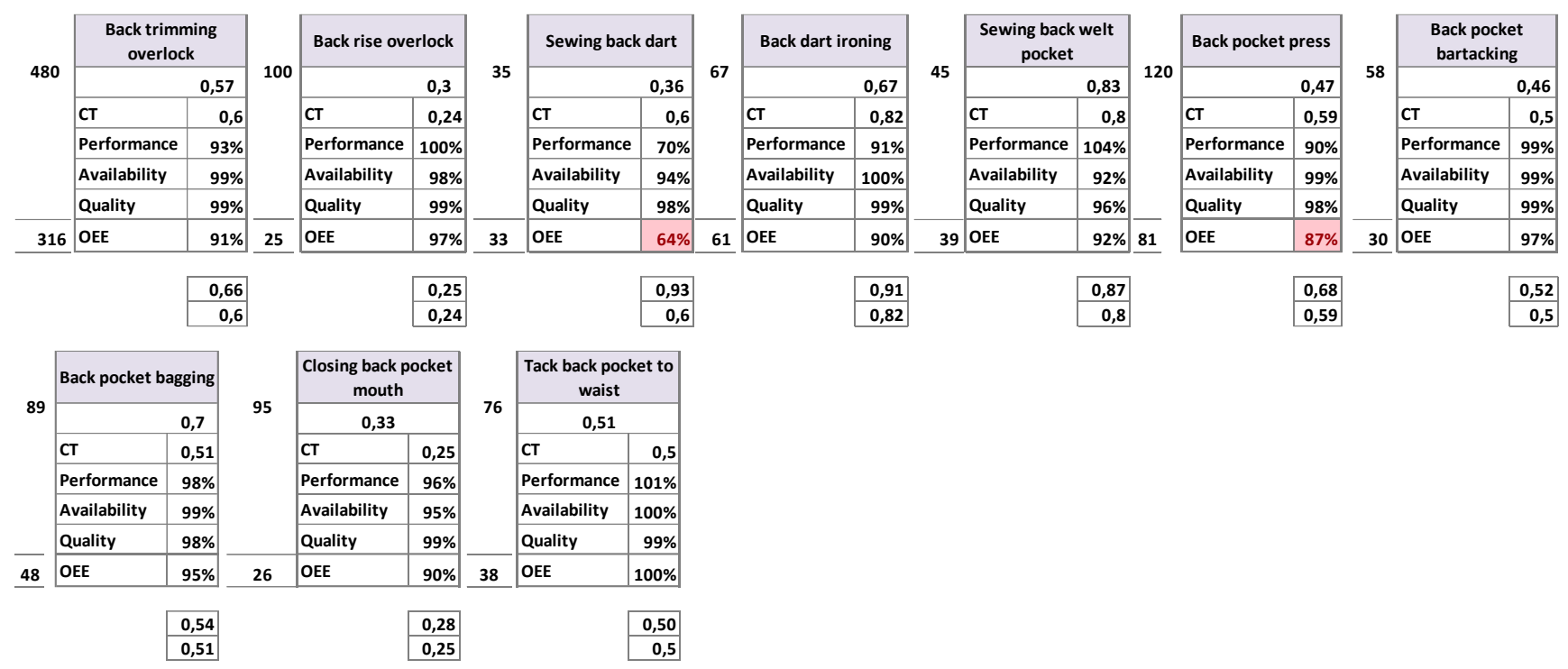

Figure 2. Value stream of men's trousers assembly line

Total cycle time is $40.84 \mathrm{~min}$, total WIP stock in the line is 6630 and total process lead time is 4762 minutes for current state as seen in Table 2. The process cycle efficiency of the current situation is $0.9 \%$. Nakajima indicated that under ideal conditions, the companies should have availability $>90 \%$, performance $>95 \%$, quality $>99 \%$ values which result in OEE $>84 \%$ and this OEE value is a good benchmark for a typical manufacturing capability [14]. When the current situation map is examined, the sources of inefficiency for each operation can be seen by checking the OEE values, which are under $85 \%$. The reasons of losses at performance, availability and the quality values should be examined in order to increase low OEE values. The improvement points and the activities to be done were determined as in Table1.

After these improvements, OEE values of 21 operations changed as given in the future state part of Table 2. As a result of the improvement studies, no changes have been observed in the information flow, material flow and raw material supply processes. Only control checking operation has been removed. Therefore, future state map was not shown again. After the elimination of this operation, the future cycle time is $40.19 \mathrm{~min}$. Improvements in availability, performance and quality ratios increased most of the OEE values over $85 \%$ and accordingly, WIP levels dropped as seen in Table 2.

In the future state, the WIP stock level has been reduced from 6630 to 4460 . The time losses because of WIP stocks have been eliminated and the total process lead time decreased from 4762 to 2702 minutes. This has led to the implementation of lean flow in production. Thus, the PCE value of the line increased from $0.9 \%$ to $1.5 \%$ and the production pace raised.

\section{CONCLUSION}

The apparel companies try to cater for the customer demands, which have high variety of models with low quantities in recent volatile market. This situation forces the companies work flexible with low costs. Therefore, the companies have to revise themselves according to the needs and expectations of their customers continuously. Lean manufacturing provides being highly responsive to customer demand while producing quality products economically and efficiently by reducing various waste in workforce, inventory, time to market. Shorter process lead time provides increasing customer satisfaction and gives flexibility to change schedules. OEE infers how much the equipment is doing compared to it is expected to do. Losses are activities that absorb resources without creating value and OEE reveals the losses that hinders equipment from performing its maximum effectiveness.

The present study aimed to find the hidden waste present in the men's trousers assembly line with the help of VSM and OEE values of operations and eventually to increase the PCE value in this line. After the calculation of OEE values of operations, the OEE values under $85 \%$ were determined. In these operations, main reason of the losses was rhythm problem, which stem from the minor stoppages and these stoppages affect the performance of the worker. Some precautions were taken to minimize the stoppages. Machine breakdowns and the setup times were the reasons of low machine availability in some operations. Machine changes and the maintenance program were planned for these wastes. In order to accelerate the speed and to overcome some quality problems, some machine changes were made. As a result of these activities, the WIP stock level in the assembly line was reduced from 6630 to 4460 pieces and the total 
process lead time decreased from 4762 to 2702 minutes. Finally, the process cycle efficiency of the line increased from $0.9 \%$ to $1.5 \%$.

OEE is one of the most important performance measurements in manufacturing companies. The companies can increase capacity, decrease costs, improve quality in production lines by optimizing OEE. It is expected that this research will be a good example of OEE application for other apparel companies.

Table 1. Problems and improvements in current situations

\begin{tabular}{|c|c|c|c|}
\hline No & OPERATION & PROBLEM & ARRANGEMENTS \\
\hline \multicolumn{4}{|c|}{ Segment 2 (Pocket preparation) } \\
\hline 1 & Pocket facing seam & Sewing adjustment & Machine to be exchanged \\
\hline 2 & Pressing fly lining & Rhythm problem & Apparatus to be made for fly pressing \\
\hline 3 & $\begin{array}{l}\text { Front pocket facing } \\
\text { overlock }\end{array}$ & Sewing adjustment problem & Machine to be exchanged \\
\hline \multicolumn{4}{|c|}{ Segment 3 (Back Piece) } \\
\hline 5 & Sewing back dart & $\begin{array}{l}\text { Long SMED time in one } \\
\text { and double dart models }\end{array}$ & $\begin{array}{l}\text { The machine will be modified in order to put apparatus on the machine for } \\
\text { both models at the same time. }\end{array}$ \\
\hline \multicolumn{4}{|c|}{ MAINLINE (Front Piece) } \\
\hline 6 & Sewing left fly & $\begin{array}{l}\text { Fly- lining notch alignment } \\
\text { problem }\end{array}$ & A nest will be made on the machine in order to align the notch. \\
\hline 7 & Facing seam & Rhythm problem & $\begin{array}{l}\text { Pieces to be sewn will be on the operator's lap and the facing pieces will be } \\
\text { stacked on the machine. The operator will take a piece from his lap and place it } \\
\text { on the machine with his two hands. After placing the facing on the piece and } \\
\text { sewing it, he will leave the finished piece to the table on the left. }\end{array}$ \\
\hline 8 & Front pocket press & Rhythm problem & $\begin{array}{l}\text { The pieces will be stacked in the direction of the press and there will be no need } \\
\text { for the worker to turn the piece for placing on the press. }\end{array}$ \\
\hline 9 & Topstitch inseam & Rhythm problem & Machine speed and type will be changed. \\
\hline 10 & $\begin{array}{l}\text { Right fly lining bagging } \\
\text { and label attaching }\end{array}$ & Fly cutting problem & Blade machine will be used to eliminate cutting time. \\
\hline 11 & Left fly foot stitch & Rhythm problem & $\begin{array}{l}\text { A line will be drawn } 1 \mathrm{~cm} \text { away from the presser foot in order to make the } \\
\text { pursuance of the sewing line easy. }\end{array}$ \\
\hline 12 & Right fly edge stitch & Rhythm problem & $\begin{array}{l}\text { An auxiliary piece will be put near to presser foot to lean the fabric for making } \\
\text { the tracking of the sewing line easy. }\end{array}$ \\
\hline 13 & Hook tacking & $\begin{array}{l}\text { Frequent machine } \\
\text { breakdown }\end{array}$ & Machine engine will be changed \\
\hline 14 & Inspection & $\begin{array}{l}\text { Hand-to-hand flow } \\
\text { deceleration between } \\
\text { operations }\end{array}$ & $\begin{array}{l}\text { The steps of control operations that affect the finished product quality will be } \\
\text { eliminated by integrating it into other operations. }\end{array}$ \\
\hline 15 & Waistband blind stitch & $\begin{array}{l}\text { Failure to set the depth of } \\
\text { needle penetration of blind } \\
\text { stitch machine }\end{array}$ & Needle and yarn number will be changed. \\
\hline 16 & Bartacking crotch & $\begin{array}{l}\text { Loss of time during } \\
\text { transport of crotch } \\
\text { components }\end{array}$ & Stock space will be made on the machine for the pieces. \\
\hline 17 & Crotch point bartacking & Rhythm problem & $\begin{array}{l}\text { In the current situation, the work piece standing at the table on the left was } \\
\text { taken, the bartacking process was done, and the work piece was moved to the } \\
\text { table on the right side. In the new case, the piece is shifted to the table, which } \\
\text { is placed in front of the sewing machine. Thus, the transport was reduced. }\end{array}$ \\
\hline 18 & Trimming blind stitch & Rhythm problem & $\begin{array}{l}\text { The worker stops more than expected in order to arrange the piece because of } \\
\text { the round and narrow shape of the hem. A guide piece will be attached around } \\
\text { the cylinder arm of the blind stitching machine. The worker will stop less with } \\
\text { the guidance of this piece. }\end{array}$ \\
\hline 19 & Sewing tape to hem & Rhythm problem & $\begin{array}{l}\text { To make the worker less stop for checking the distance from edge of hem, } \\
\text { laser light will be used to keep the distance }\end{array}$ \\
\hline 20 & Trousers cuffs pressing & Rhythm problem & $\begin{array}{l}\text { For decreasing the bundle transporting time, another bundle holding apparatus } \\
\text { will be put oppose the current one. }\end{array}$ \\
\hline 21 & Leg Press & $\begin{array}{l}\text { Failure to set machine } \\
\text { according to fabric type. }\end{array}$ & $\begin{array}{l}\text { All machine maintenance will be done and upper buck material will be } \\
\text { changed with } 10 \mathrm{~mm} \text { thick silicone foam. This material will prevent shine and } \\
\text { pressure problem and reduce the time for setting machine. }\end{array}$ \\
\hline 22 & Creasing press & $\begin{array}{l}\text { Failure of size fixing during } \\
\text { ceasing press and chronic } \\
\text { machine failure }\end{array}$ & $\begin{array}{l}\text { The machine will be maintained every week and the laser will be installed at } \\
\text { the starting and end points to prevent the measurement problem for ceasing. }\end{array}$ \\
\hline
\end{tabular}


Table 2. Comparison of current and future state

\begin{tabular}{|c|c|c|c|c|c|c|c|c|c|c|c|c|c|c|c|}
\hline \multirow[b]{2}{*}{ Segment 1(Belt preparation) } & \multicolumn{8}{|c|}{ CURRENT STATE } & \multicolumn{7}{|c|}{ FUTURE STATE } \\
\hline & $\begin{array}{l}\text { Cycle } \\
\text { time }\end{array}$ & \begin{tabular}{|c|} 
Actual \\
cycle time
\end{tabular} & Performance & Availability & Quality & OEE & WIP & PLT & Performance & Availability & Quality & OEE & \begin{tabular}{|c|} 
Actual \\
cycle time
\end{tabular} & WIP & PLT \\
\hline Belt fusing & 0,26 & 0,26 & $100 \%$ & $100 \%$ & $99 \%$ & $99 \%$ & 467 & 121 & $100 \%$ & $100 \%$ & $99 \%$ & $99 \%$ & 0,26 & 230 & 59 \\
\hline Belt lining & 0,47 & 0,48 & $99 \%$ & $98 \%$ & $100 \%$ & $97 \%$ & 250 & 121 & $99 \%$ & $98 \%$ & $100 \%$ & $97 \%$ & 0,48 & 45 & 22 \\
\hline Loop attaching & 0,35 & 0,41 & $102 \%$ & $95 \%$ & $89 \%$ & $86 \%$ & 100 & 41 & $102 \%$ & $95 \%$ & $89 \%$ & $86 \%$ & 0,41 & 90 & 37 \\
\hline Waistband press & 0,9 & 0,96 & $100 \%$ & $99 \%$ & $95 \%$ & $94 \%$ & 160 & 153 & $100 \%$ & $99 \%$ & $95 \%$ & $94 \%$ & 0,96 & 70 & 67 \\
\hline $\begin{array}{l}\text { Segment } 2 \text { (Pocket } \\
\text { preparation) }\end{array}$ & $\begin{array}{l}\text { Cycle } \\
\text { time }\end{array}$ & $\begin{array}{c}\text { Actual } \\
\text { cycle time }\end{array}$ & Performance & Availability & Quality & OEE & WIP & PLT & Performance & Availability & Quality & OEE & $\begin{array}{c}\text { Actual } \\
\text { cycle time }\end{array}$ & WIP & PLT \\
\hline Pocket facing seam & 0,98 & 1,37 & $98 \%$ & $80 \%$ & $91 \%$ & $71 \%$ & 660 & 907 & $100 \%$ & $95 \%$ & $96 \%$ & $91 \%$ & 1,07 & 450 & 484 \\
\hline Fusing fly & 0,17 & 0,17 & $99 \%$ & $100 \%$ & $100 \%$ & $99 \%$ & 436 & 75 & $99 \%$ & $100 \%$ & $100 \%$ & $99 \%$ & 0,17 & 375 & 64 \\
\hline Pressing fly lining & 0,15 & 0,19 & $77 \%$ & $100 \%$ & $100 \%$ & $77 \%$ & 120 & 23 & $92 \%$ & $100 \%$ & $100 \%$ & $92 \%$ & 0,16 & 70 & 11 \\
\hline Zipper attaching to fly & 0,17 & 0,18 & $100 \%$ & $98 \%$ & $97 \%$ & $95 \%$ & 130 & 23 & $100 \%$ & $98 \%$ & $97 \%$ & $95 \%$ & 0,18 & 95 & 17 \\
\hline Front pocket facing overlock & 0,32 & 0,56 & $90 \%$ & $80 \%$ & $80 \%$ & $58 \%$ & 230 & 128 & $95 \%$ & $99 \%$ & $98 \%$ & $92 \%$ & 0,35 & 375 & 130 \\
\hline Mainline (Front piece) & $\begin{array}{l}\text { Cycle } \\
\text { time }\end{array}$ & $\begin{array}{c}\text { Actual } \\
\text { cycle time }\end{array}$ & Performance & Availability & Quality & OEE & WIP & PLT & Performance & Availability & Quality & OEE & $\begin{array}{c}\text { Actual } \\
\text { cycle time }\end{array}$ & WIP & PLT \\
\hline Color seperation and opening & 0,64 & 0,64 & $100 \%$ & $100 \%$ & $100 \%$ & $100 \%$ & 500 & 320 & $100 \%$ & $100 \%$ & $100 \%$ & $100 \%$ & 0,64 & 475 & 304 \\
\hline $\begin{array}{l}\text { Color seperation and } \\
\text { dispatching }\end{array}$ & 0,04 & 0,04 & $100 \%$ & $100 \%$ & $100 \%$ & $100 \%$ & 230 & 9 & $100 \%$ & $100 \%$ & $100 \%$ & $100 \%$ & 0,04 & 200 & 8 \\
\hline Front cuff overlock & 0,92 & 1,00 & $102 \%$ & $95 \%$ & $95 \%$ & $92 \%$ & 475 & 474 & $102 \%$ & $95 \%$ & $95 \%$ & $92 \%$ & 1,00 & 90 & 90 \\
\hline Frontcrotch overlock & 0,75 & 0,81 & $99 \%$ & $97 \%$ & $96 \%$ & $92 \%$ & 120 & 98 & $95 \%$ & $100 \%$ & $96 \%$ & $91 \%$ & 0,82 & 0 & 0 \\
\hline Sewing right fly & 0,27 & 0,28 & $99 \%$ & $98 \%$ & $99 \%$ & $96 \%$ & 79 & 22 & $100 \%$ & $98 \%$ & $99 \%$ & $97 \%$ & 0,28 & 45 & 13 \\
\hline Sewing left fly & 0,45 & 0,54 & $86 \%$ & $98 \%$ & $99 \%$ & $83 \%$ & 105 & 57 & $95 \%$ & $98 \%$ & $99 \%$ & $92 \%$ & 0,49 & 45 & 22 \\
\hline Facing seam & 0,67 & 0,89 & $88 \%$ & $92 \%$ & $93 \%$ & $75 \%$ & 150 & 133 & $98 \%$ & $92 \%$ & $93 \%$ & $84 \%$ & 0,80 & 45 & 36 \\
\hline Front pocket press & 0,21 & 0,26 & $82 \%$ & $100 \%$ & $99 \%$ & $81 \%$ & 40 & 10 & $95 \%$ & $100 \%$ & $99 \%$ & $94 \%$ & 0,22 & 40 & 9 \\
\hline Side pocket tacking & 1,78 & 1,78 & $100 \%$ & $100 \%$ & $100 \%$ & $100 \%$ & 67 & 119 & $100 \%$ & $100 \%$ & $100 \%$ & $100 \%$ & 1,78 & 45 & 80 \\
\hline Front pocket bagging & 0,52 & 0,56 & $94 \%$ & $100 \%$ & $99 \%$ & 93\% & 66 & 37 & $100 \%$ & $100 \%$ & $99 \%$ & $99 \%$ & 0,53 & 45 & 24 \\
\hline Sewing sides & 1,4 & 1,46 & $99 \%$ & $99 \%$ & $98 \%$ & $96 \%$ & 90 & 131 & $100 \%$ & $99 \%$ & $98 \%$ & $97 \%$ & 1,44 & 50 & 72 \\
\hline Top stitch inseam & 0,6 & 0,71 & $96 \%$ & $94 \%$ & $93 \%$ & $84 \%$ & 78 & 56 & $97 \%$ & $100 \%$ & $95 \%$ & $92 \%$ & 0,65 & 20 & 13 \\
\hline Press side in seams & 0,7 & 0,72 & $107 \%$ & $98 \%$ & $93 \%$ & $98 \%$ & 130 & 93 & $105 \%$ & $98 \%$ & $93 \%$ & $96 \%$ & 0,73 & 45 & 33 \\
\hline Attaching waistband & 1,72 & 1,86 & $105 \%$ & $98 \%$ & $90 \%$ & $93 \%$ & 78 & 145 & $105 \%$ & $98 \%$ & $90 \%$ & $93 \%$ & 1,86 & 45 & 84 \\
\hline $\begin{array}{l}\text { Right fly lining bagging and } \\
\text { label attaching }\end{array}$ & 0,75 & 1,02 & $90 \%$ & $90 \%$ & $91 \%$ & $74 \%$ & 40 & 41 & $93 \%$ & $98 \%$ & $99 \%$ & $90 \%$ & 0,83 & 0 & 0 \\
\hline Left belt end finishing & 0,25 & 0,26 & $100 \%$ & $99 \%$ & $98 \%$ & $97 \%$ & 27 & 7 & $100 \%$ & $99 \%$ & $98 \%$ & $97 \%$ & 0,26 & 35 & 9 \\
\hline Right and left belt end ironing & 0,59 & 0,60 & $104 \%$ & $95 \%$ & $100 \%$ & $99 \%$ & 35 & 21 & $104 \%$ & $95 \%$ & $100 \%$ & $99 \%$ & 0,60 & 35 & 21 \\
\hline Left fly foot stitch & 0,45 & 0,58 & $89 \%$ & $95 \%$ & $92 \%$ & $78 \%$ & 21 & 12 & $99 \%$ & $96 \%$ & $95 \%$ & $90 \%$ & 0,50 & 21 & 10 \\
\hline Sewing right fly & 0,38 & 0,47 & $86 \%$ & $100 \%$ & $95 \%$ & $82 \%$ & 25 & 12 & $100 \%$ & $100 \%$ & $95 \%$ & $95 \%$ & 0,40 & 25 & 10 \\
\hline Hook tacking & 0,35 & 0,48 & $86 \%$ & $86 \%$ & $98 \%$ & $72 \%$ & 14 & 7 & $93 \%$ & $100 \%$ & $98 \%$ & $91 \%$ & 0,38 & 14 & 5 \\
\hline Stop & 0,3 & 0,33 & $100 \%$ & $95 \%$ & $95 \%$ & $90 \%$ & 22 & 7 & $100 \%$ & $95 \%$ & $95 \%$ & $90 \%$ & 0,33 & 22 & 7 \\
\hline Point check & 0,65 & 1,58 & $42 \%$ & $100 \%$ & $98 \%$ & $41 \%$ & 35 & 55 & \multicolumn{7}{|c|}{ ELIMINATED } \\
\hline Back rise closure & 1,71 & 1,82 & $108 \%$ & $98 \%$ & $89 \%$ & $94 \%$ & 100 & 182 & $108 \%$ & $98 \%$ & $89 \%$ & $94 \%$ & 1,82 & 45 & 82 \\
\hline Back rise sewing and pressing & 0,56 & 0,58 & $104 \%$ & $98 \%$ & $95 \%$ & $96 \%$ & 20 & 12 & $104 \%$ & $98 \%$ & $95 \%$ & $97 \%$ & 0,58 & 20 & 12 \\
\hline Waistband blindstitch & 0,62 & 0,77 & $98 \%$ & $91 \%$ & $90 \%$ & $80 \%$ & 34 & 26 & $100 \%$ & $95 \%$ & $94 \%$ & $89 \%$ & 0,69 & 34 & 24 \\
\hline Crotch Bartacking & 0,2 & 0,53 & $42 \%$ & $98 \%$ & $92 \%$ & $38 \%$ & 55 & 29 & $98 \%$ & $98 \%$ & $94 \%$ & $90 \%$ & 0,22 & 20 & 4 \\
\hline Crotch point bartacking & 0,7 & 1,04 & $74 \%$ & $93 \%$ & $98 \%$ & $67 \%$ & 12 & 12 & $98 \%$ & $95 \%$ & $98 \%$ & $91 \%$ & 0,77 & 12 & 9 \\
\hline Pocket and loop bartacking & 1,8 & 1,97 & $107 \%$ & $95 \%$ & $90 \%$ & $91 \%$ & 35 & 69 & $107 \%$ & $95 \%$ & $90 \%$ & $91 \%$ & 1,97 & 35 & 69 \\
\hline Bartacking & 0,53 & 0,54 & $102 \%$ & $98 \%$ & $98 \%$ & $98 \%$ & 45 & 24 & $102 \%$ & $98 \%$ & $98 \%$ & $98 \%$ & 0,54 & 45 & 24 \\
\hline Check before pressing & 1,7 & 1,73 & $100 \%$ & $100 \%$ & $98 \%$ & $98 \%$ & 50 & 87 & $100 \%$ & $100 \%$ & $98 \%$ & $98 \%$ & 1,73 & 50 & 87 \\
\hline Trimming blindstitch & 0,29 & 0,58 & $56 \%$ & $95 \%$ & $94 \%$ & $50 \%$ & 65 & 38 & $86 \%$ & $100 \%$ & $94 \%$ & $81 \%$ & 0,36 & 35 & 13 \\
\hline Cuff press & 0,47 & 1,37 & $38 \%$ & $95 \%$ & $95 \%$ & $34 \%$ & 19 & 26 & $83 \%$ & $95 \%$ & $95 \%$ & $75 \%$ & 0,63 & 0 & 0 \\
\hline Sewing trimming band & 0,46 & 0,95 & $52 \%$ & $97 \%$ & $96 \%$ & $48 \%$ & 3 & 3 & $90 \%$ & $97 \%$ & $96 \%$ & $84 \%$ & 0,55 & 5 & 3 \\
\hline Leg Press & 1,05 & 1,30 & $100 \%$ & $84 \%$ & $96 \%$ & $81 \%$ & 15 & 20 & $100 \%$ & $94 \%$ & $96 \%$ & $90 \%$ & 1,16 & 15 & 17 \\
\hline Pressing & 3,4 & 3,58 & $95 \%$ & $100 \%$ & $100 \%$ & $95 \%$ & 5 & 18 & $97 \%$ & $100 \%$ & $100 \%$ & $97 \%$ & 3,51 & 5 & 18 \\
\hline Ceasing press & 0,8 & 1,23 & $90 \%$ & $85 \%$ & $85 \%$ & $65 \%$ & 10 & 12 & $100 \%$ & $95 \%$ & $85 \%$ & $81 \%$ & 0,99 & 10 & 10 \\
\hline Final inspection & 2,98 & 3,03 & $100 \%$ & $100 \%$ & $98 \%$ & $98 \%$ & 17 & 52 & $100 \%$ & $100 \%$ & $98 \%$ & $98 \%$ & 3,04 & 17 & 52 \\
\hline Segment 3 (Back Piece) & $\begin{array}{l}\text { Cycle } \\
\text { time }\end{array}$ & $\begin{array}{c}\text { Actual } \\
\text { cycle time }\end{array}$ & Performance & Availability & Quality & OEE & WIP & PLT & Performance & Availability & Quality & OEE & $\begin{array}{c}\text { Actual } \\
\text { cycle time }\end{array}$ & WIP & PLT \\
\hline Back trimming overlock & 0,6 & 0,66 & $93 \%$ & $99 \%$ & $99 \%$ & $91 \%$ & 480 & 316 & $100 \%$ & $95 \%$ & $95 \%$ & $90 \%$ & 0,66 & 475 & 316 \\
\hline Back rise overlock & 0,24 & 0,25 & $100 \%$ & $98 \%$ & $99 \%$ & $97 \%$ & 100 & 25 & $100 \%$ & $98 \%$ & $99 \%$ & $97 \%$ & 0,25 & 200 & 49 \\
\hline Sewing back dart & 0,6 & 0,93 & $70 \%$ & $94 \%$ & $98 \%$ & $64 \%$ & 35 & 33 & $97 \%$ & $96 \%$ & $98 \%$ & $91 \%$ & 0,66 & 90 & 59 \\
\hline Back dart ironing & 0,82 & 0,91 & $91 \%$ & $100 \%$ & $99 \%$ & $90 \%$ & 67 & 61 & $91 \%$ & $100 \%$ & $99 \%$ & $90 \%$ & 0,91 & 0 & 0 \\
\hline Sewing back welt pocket & 0,8 & 0,87 & $104 \%$ & $92 \%$ & $96 \%$ & $92 \%$ & 45 & 39 & $104 \%$ & $92 \%$ & $96 \%$ & $92 \%$ & 0,87 & 45 & 39 \\
\hline Back pocket press & 0,59 & 0,68 & $90 \%$ & $99 \%$ & $98 \%$ & $87 \%$ & 120 & 81 & $98 \%$ & $99 \%$ & $98 \%$ & $95 \%$ & 0,62 & 25 & 16 \\
\hline Back pocket bartacking & 0,5 & 0,52 & $99 \%$ & $99 \%$ & $99 \%$ & $97 \%$ & 58 & 30 & $99 \%$ & $99 \%$ & $99 \%$ & $97 \%$ & 0,52 & 45 & 23 \\
\hline Back pocket bagging & 0,51 & 0,54 & $98 \%$ & $99 \%$ & $98 \%$ & $95 \%$ & 89 & 48 & $100 \%$ & $99 \%$ & $98 \%$ & $97 \%$ & 0,53 & 45 & 24 \\
\hline Closing back pocket mouth & 0,25 & 0,28 & $96 \%$ & $95 \%$ & $99 \%$ & $90 \%$ & 95 & 26 & $100 \%$ & $92 \%$ & $99 \%$ & $91 \%$ & 0,27 & 45 & 12 \\
\hline Tack back pocket to waist & 0,5 & 0,50 & $101 \%$ & $100 \%$ & $99 \%$ & $100 \%$ & 76 & 38 & $101 \%$ & $100 \%$ & $99 \%$ & $100 \%$ & 0,50 & 0 & 0 \\
\hline $\begin{array}{ll}\text { Total } \\
\end{array}$ & 40,84 & & & & & & 6630 & 4762 & & & & & & 4460 & 2702 \\
\hline
\end{tabular}




\section{REFERENCES}

1. Singh B, Sharma SK. 2009. Value stream mapping as a versatile tool for lean implementation: An Indian case study of a manufacturing firm. Measuring Business Excellence 13(3), 58-68, https://doi.org/10.1108/13683040910984338.

2. Russell RS, Taylor BW. 1999. Operations Management, 2nd ed. Prentice-Hall, Upper Saddle River.

3. Hines P, Rich N. 1997. The seven value stream mapping tools. International Journal of Operations \& Production Management 17(1), 46-64.

4. Womack JP, Jones DT. 2003. Lean thinking: Banish waste and create wealth in your Corporation. 2nd ed., London, UK: Simon and Schuster Inc., 15-90.

5. Rother M, Shook J. 1999. Learning to See: Value Stream Mapping to Create Value and Eliminate Muda. Learning Enterprise Institute, Brookline.

6. Kumar BS, Thavaraj HS. 2015. Impact of Lean Manufacturing Practices on Clothing Industry Performance. International Journal of Textile and Fashion Technology 5(2), 1-14.

7. Brandt E. Tjärning A. 2015. Changing from a reactive to a proactive maintenance culture; Implementing of OEE. Lulea University of Technology Engineering Programme, Master Thesis.

8. Sudhakar S. 2015. Value stream mapping and value stream design in a complex diesel pump production flow: A case study. Journal of Mechanical Engineering and Automation 5(3B), 69-75.

9. Kumari R, Quazi TZ, Kumar R. 2015. Application of lean manufacturing tools in garment industry. International Journal Of Mechanical Engineering And Information Technology 3(1), 976-982.

10. Akçagün E, Dal V, Yılmaz A. 2012. Using value stream mapping at apparel industry: A case study. In Proceedings of the 6th International Textile, Clothing \& Design Conference - Magic World of Textiles October 07-10 2012, Dubrovnik, Croatia.

11. Yildız EZ, Güner M. 2013. Applying value stream mapping technique in apparel industry. Tekstil ve Konfeksiyon 23(4), 393-400.

12. Silva S. 2012. Applicability of value stream mapping (VSM) in the apparel industry in Sri Lanka. International Journal of Lean Thinking 3(1), 36-41.

13. Kumar BS. 2016. Value stream mapping-a lean manufacturing approach to reduce the process wastages in clothing industry. International Journal of Advances in Management and Economics V5(5), 23-33.

14. Bamber CJ, Castka P, Sharp JM, Motara Y. 2003. Cross-functional team working for overall equipment effectiveness(OEE). Journal of Quality in Maintenance Engineering 9(3), 223-238. 